\title{
Aminoethoxyvinylglycine, Combined with Ethephon, Can Enhance Red Color Development without Over-ripening Apples
}

\author{
Zhenyong Wang ${ }^{1}$ and David R. Dilley ${ }^{2}$ \\ Department of Horticulture, Michigan State University, East Lansing, \\ MI 48824-1325

\begin{abstract}
Additional index words. ethylene, ethylene climacteric, fruit maturity, CA storage, flesh firmness, shelf-life, ReTain ${ }^{\mathrm{TM}}$, Malus $\times$ domestica
\end{abstract}

\begin{abstract}
AVG, as ReTain ${ }^{\mathrm{TM}}$, an inhibitor of ethylene biosynthesis, was used alone or with a subsequent application of ethephon $\left(\right.$ Ethrel $\left.^{\mathrm{TM}}\right)$, an ethylene-releasing chemical, to determine if red color development could be enhanced without over-ripening 'Gala' and 'Jonagold' apples. Treatments included: 1) AVG alone; 2) AVG followed by ethephon; 3) ethephon alone; and 4) control. Silwet L-77 surfactant was included in all treatments. Application of AVG delayed the onset of the ethylene climacteric and red color development of both cultivars. Application of AVG followed by ethephon similarly delayed the onset of the ethylene climacteric, but red color development at the commercial harvest date was only marginally reduced or not affected. The results were similar in both 1998 and 1999, although environmental stress during the growing seasons differed (1998 - heat; 1999 — moderate temperatures). The delay of fruit maturation and ripening observed at harvest following AVG +/- ethephon treatments improved storability of fruit in controlled atmosphere (CA) storage, as demonstrated by low internal ethylene levels after storage, and high retention of flesh firmness and shelf-life, while control fruit and those treated only with ethephon entered the ethylene climacteric during storage, and flesh firmness subsequently declined during shelf-life evaluation. Chemical name used: aminoethoxyvinylglycine (AVG).
\end{abstract}

Multiple harvests are often necessary to achieve maximum yield of well-colored, highquality apples of cultivars, such as 'Gala' and 'Jonagold', adding to the cost of production. Red color development can be improved and preharvest fruit abscission delayed by applying naphthaleneacetic acid (NAA), but this may stimulate ethylene production and ripening. Ethephon, an ethylene-releasing chemical, can be used to improve red color development, but it also stimulates ripening, and fruit so treated have a very limited storage life. Earlier studies (Murphey and Dilley, 1988)

\footnotetext{
Received for publication 13 Mar. 2000. Accepted for publication 28 Aug. 2000. We gratefully acknowledge the financial support of the Michigan State Horticultural Society Trust Fund, the Michigan Apple Research Committee and the Michigan Agricultural Experiment Station, which made these studies possible. We also thank the staff at the Michigan State Univ. Clarksville Horticultural Experiment Station (Jerry Skeltis, Gail Byler, Brian Kropf, Ronald Perry, and Philip Schwallier) for their help, and Toni Warner, Leonardo Lombardini, Andriana Nikoloudi, Sarah Bruce, Steve Riley, Ryan VanAgtmael, and Dina Kadyrzhanova for technical assistance in conducting these investigations. The cost of publishing this paper was defrayed in part by the payment of page charges. Under postal regulations, this paper therefore must be hereby marked advertisement solely to indicate this fact.

${ }^{1}$ Research Associate. E-mail address: wangzhe1@ msu.edu

${ }^{2}$ Professor. E-mail address: dilley@msu.edu
}

training systems, including rootstocks EMLA.9 and 27, Ottawa 3, B.9, and MARK in each main block, with vertical axis or slender spindle training systems at various tree spacings, were used as replicates.

Treatments applied. Chemical usage rates were: 1$) \operatorname{AVG}\left(124 \mathrm{~g} \cdot \mathrm{ha}^{-1}\right)$ applied $\approx 4$ to 5 weeks prior to the predicted harvest date for nontreated fruit; 2) AVG followed by ethephon $\left(212 \mathrm{~g} \cdot \mathrm{ha}^{-1}\right.$ in 1998 , and $282 \mathrm{~g} \cdot \mathrm{ha}^{-1}$ in 1999) applied 1 to 2 weeks prior to harvest; 3) ethephon alone; and 4) control [Silwet L-77 surfactant only $0.1 \%(\mathrm{v} / \mathrm{v})$, which was also used with the AVG and ethephon treatments]. The usage rate for ethephon at $282 \mathrm{~g} \cdot \mathrm{ha}^{-1}$ is the full-strength rate for use on apple for color enhancement. Chemicals were applied using an air-blast sprayer at $934 \mathrm{~L} \cdot \mathrm{ha}^{-1}$. Commercially available ReTain ${ }^{\mathrm{TM}}$ (Abbott Laboratories, Chicago) and Ethrel ${ }^{\mathrm{TM}}$ (Rhone-Poulenc, Research Triangle Park, N.C.) were the sources of AVG and ethephon, respectively. At least three replicates for each treatment were employed each year and five to eight trees in each experimental unit (replicate) were selected at random before harvest time within one of four main blocks containing at least three of the various rootstock/training systems. The selected trees of each cultivar in one treatment had the same rootstock/training systems and tree spacings as in the other treatments. This provided a wide range of tree-to-tree variation to test the main effects of treatments. In 1998 and 1999, 'Gala' trees received AVG or surfactant treatments on 11 and 5 Aug., respectively; ethephon or surfactant treatments were applied on 31 and 23 Aug., respectively. 'Jonagold' trees received AVG or surfactant treatments on 24 and 23 Aug. in 1998 and 1999, respectively; ethephon or surfactant treatments were applied on 14 and 8 Sept., respectively.

Evaluation. Fruit samples from each treatment (30 to 40 fruit) were randomly harvested from five to eight trees of each cultivar in each block at 3- to 4-d intervals beginning 2 weeks prior to the estimated commercial harvest date for the control. Samples of fruit of each treatment at the commercial harvest time in 1999, including 10 replicates of 'Gala' and six replicates of 'Jonagold', were held separately under controlled-atmosphere (CA) storage, using a ventilated $\mathrm{CA}$ system under $1.5 \% \mathrm{O}_{2}+$ $3 \% \mathrm{CO}_{2}$ at $1{ }^{\circ} \mathrm{C}$ to evaluate fruit storability (CA storage studies were not conducted in 1998). The atmospheres in this CA system were generated with an air separator $\left(\right.$ Permea $^{\mathrm{TM}}$, model 5; Permea, St. Louis) and distributed through a capillary flow board system for maintaining controlled atmospheres in a dynamic flow-through mode. Quality parameters evaluated at each harvest and after 1 week at $20^{\circ} \mathrm{C}$ included: internal ethylene [gas chromatography (Hach Carle Series 100 AGC, Loveland, Colo.) with alumina column and flame ionization detector]; development of red color (percentage of red) and ground color index $(1=$ green and $5=$ yellow $)$; flesh firmness [Effegi penetrometer (Effegi, Alfonsine, Italy) with 11-mm tip]; starch index $(1=$ high and $9=$ low $)$ and Brix value 
(percentage of soluble solids) [hand refractometer (Atago ATC-1E; Cole-Parmer Instrument, Japan)] using 10 fruit per replicate. Fruit (20 per replicate) were examined for internal ethylene concentrations and quality parameters upon removal from storage and after $7 \mathrm{~d}$ in air at $20^{\circ} \mathrm{C}$. Internal ethylene concentration is an indirect measurement of ethylene production rate for apple (Burg and Burg, 1965). Since the fruit from each treatment were held separately during ventilated CA storage, this procedure provided a valid assessment of treatment effects on the development of the ethylene climacteric.

Statistical analysis. The data were analyzed based on a randomized block design. Each block consisted of 172 trees of three to five rootstocks and three training systems. Analysis of variance (ANOVA) was used to determine the significance of treatment differences by ANOVA at $P \leq 0.05$. Standard errors were calculated based upon three to five replicates of 10 fruit each.

\section{Results}

Studies on 'Gala' in 1998 and 1999. In 1998 , the onset of the ethylene climacteric for 'Gala' apples from ethephon-only and control treatments occurred on 3 Sept., whereas it was greatly inhibited by the AVG and AVG + ethephon treatments, as measured at harvest and after holding fruit in air at $20^{\circ} \mathrm{C}$ for $7 \mathrm{~d}$ (Fig. 1 A and C). In 1999, AVG treatment, with or without a follow-up application of ethephon, clearly delayed the onset of the ethylene climacteric (Fig. $1 \mathrm{E}$ and G). No significant differences were observed between the ethephon-treated and control fruit, which had entered the climacteric by 30 Aug., whereas a slowly-developing climacteric commenced $\approx 10 \mathrm{~d}$ later in the AVG +/- ethephon-treated fruit (Fig. $1 \mathrm{E}$ and G), as in 1998.

In 1998, red color development was significantly delayed by treatment with AVG alone, and treatment with ethephon at 212 $\mathrm{g} \cdot \mathrm{ha}^{-1}$ did not fully overcome the AVG effect, even by the time of commercial harvest (14 Sept.) (Fig. 1B). In 1999, AVG applied alone delayed red color development relative to control and ethephon-only treatments, while $\mathrm{AVG}+$ ethephon-treated fruit were intermediate in color development, which was slightly improved relative to that of fruit treated with AVG alone (Fig. 1F and Table 1). By 9 Sept., red color development was between $73 \%$ to $81 \%$ for fruit from all treatments. Color development continued for fruit held in the dark at $20{ }^{\circ} \mathrm{C}$ for $7 \mathrm{~d}$, but no treatment differences were significant (data not shown).

In 1998, flesh firmness of AVG +/ethephon treated fruit after $7 \mathrm{~d}$ at $20^{\circ} \mathrm{C}$ was higher at the later harvest dates than that of fruit from all other treatments (Fig. 1D). At the commercial harvest date (14 Sept.), AVG +/ethephon treated fruit were 10 to $12 \mathrm{~N}$ firmer than ethephon-only or control fruit (Fig. 1D and Table 1). Starch conversion was delayed by $\approx 1$ week in the AVG +/- ethephon-treated 'Gala' fruit (data not shown). The increase in Brix values reflected the trends observed for the decline in starch index (data not shown). In 1999, flesh firmness at harvest was similar regardless of treatment (data not shown). However, after holding the fruit in air at $20^{\circ} \mathrm{C}$ for $7 \mathrm{~d}, \mathrm{AVG}+$ ethephon-treated fruit was 4.5 $\mathrm{N}$ firmer than that of ethephon-only fruit and $3.7 \mathrm{~N}$ firmer than control fruit (Fig. 1H). Although the differences were not large, they were significant, confirming similar results in 1998. Starch conversion at commercial harvest was clearly delayed in fruit from the AVG +/ethephon treatments relative to control and ethephon-only fruit (data not shown), and this delay persisted during $7 \mathrm{~d}$ in air at $20{ }^{\circ} \mathrm{C}$, as judged by Brix values. After holding the fruit for $7 \mathrm{~d}$ at $20^{\circ} \mathrm{C}$, Brix values were inversely related to starch index. Brix values for $\mathrm{AVG}+/-$ ethephon fruit were $\approx 0.8 \%$ lower than those of control and ethephon-only fruit harvested on 25 Aug. (data not shown). The differences among treatments decreased as harvest was delayed.

Studies on 'Jonagold' in 1998 and 1999. In 1998 , the onset of the ethylene climacteric of 'Jonagold' was strongly inhibited by treatment with AVG +/- ethephon (Fig. 2, A and C); these fruit were still preclimacteric on the date of commercial harvest (28 Sept.) as judged by low ethylene levels after $7 \mathrm{~d}$ at $20{ }^{\circ} \mathrm{C}$. Control fruit and those treated only with ethephon entered the ethylene climacteric by 24 Sept. In 1999, the onset of the ethylene climacteric of 'Jonagold' fruit treated with $\mathrm{AVG}+/-$ ethephon was again significantly delayed at harvest (Fig. 2E) and this delay persisted after holding them in air at $20^{\circ} \mathrm{C}$ for 7 d (Fig. 2G). Ethephon stimulated the onset of the ethylene climacteric prior to the first harvest on 10 Sept. 1999. Climacteric onset was evident in control fruit harvested on 20 Sept.

In 1998, red or yellow color (data not shown) development had not been affected by the treatments by the time of commercial harvest on 28 Sept. (Fig. 2B). Red color gradually increased from $\approx 20 \%$ to $40 \%$ from 14 to 28 Sept. In 1999, treatment with AVG alone delayed, whereas treatment with ethephon alone at $282 \mathrm{~g} \cdot \mathrm{ha}^{-1}$ enhanced, red color development (Fig. 2F and Table 1). More importantly, ethephon applied to AVG-treated fruit stimulated red color development (Fig. 2F) without inducing the ethylene climacteric (Fig. 2, E and G). Fruit treated with AVG + ethephon were nearly as well-colored as the fruit from the ethephon-only treatment when harvested on 20 Sept., and were better colored than fruit treated with AVG only (Fig. 2F and Table 1).

In 1998, flesh firmness of AVG +/- ethephon-treated fruit was 3-5 $\mathrm{N}$ greater than that of ethephon-only or control fruit after holding them for $7 \mathrm{~d}$ at $20{ }^{\circ} \mathrm{C}$ after the commercial harvest date; firmness gradually decreased from $\approx 75$ to $65 \mathrm{~N}$ over the harvest period (Fig. 2D). Starch conversion was similar for fruit from all treatments at the later harvest dates (data not shown). In 1999, no significant differences between the control and AVG + ethephon treatments were evident in the other maturity-linked development parameters measured, including firmness (Fig. 2H), and the values of these parameters generally fell between those for the ethephon-only and the AVG-only treatments (data not shown). This was most notable for Brix values (data not shown), which can be largely explained by ethephon stimulation of starch conversion and the retardation of this process by AVG as a direct consequence of enhancing or delaying the ethylene-induced stimulation of respiratory metabolism.

Studies on 'Gala' and 'Jonagold' after CA storage in 1999. After 6 months of CA storage plus $7 \mathrm{~d}$ at $20^{\circ} \mathrm{C}$, the ethylene production of 'Gala' fruit harvested on 9 Sept. (commercial harvest date), whether treated with ethephon or not, was still significantly inhibited by AVG treatments (Table 2). This effect was retained for 'Gala' fruit during the shelf-life period at $20{ }^{\circ} \mathrm{C}$. These effects reflected differences between treatments noted for 'Gala' fruit measured at harvest. After 6 months of CA storage and $7 \mathrm{~d}$ at $20^{\circ} \mathrm{C}$, as at harvest time, red color of 'Gala' was significantly greater with AVG + ethephon than for AVG alone, but less than that for the control and for ethephon only. After 6 months of CA storage and $7 \mathrm{~d}$ at $20^{\circ} \mathrm{C}$, retention of flesh firmness of 'Gala' apples treated with AVG +/- ethephon was greater than that of control fruit or those treated with ethephon alone (Table 2). Retention of flesh firmness during storage was improved significantly by AVG treatment.

For 'Jonagold', after 6 months of CA storage and $7 \mathrm{~d}$ at $20^{\circ} \mathrm{C}$, ethylene production was still inhibited by AVG treatments (Table 2), however, red color was almost as well developed in AVG + ethephon-treated fruit as in control fruit, while apples treated with AVG alone had fair red color development (Table 2 ). Treatment with ethephon alone enhanced fruit softening (Table 2).

\section{Discussion}

In two consecutive years, AVG applied alone delayed the onset of the ethylene climacteric and red color development of 'Gala' and 'Jonagold' apples, confirming other observations (Bangerth, 1978; Shafer et al., 1995; Wang and Dilley, 1998). Application of AVG followed by ethephon delayed the onset of the ethylene climacteric, and red color development at commercial harvest was significantly improved in comparison with that of fruit treated with AVG alone using a higher ethephon rate $\left(282 \mathrm{~g} \cdot \mathrm{ha}^{-1}\right)$ as was done in 1999. This indirectly confirms the results of Bangerth (1978) who observed that AVG prevented autocatalytic ethylene production initiated by NAA or 2,4,5-trichlorophenoxyacetic acid (2,4,5-TP) if applied alone. Both NAA and 2,4,5-TP are known to promote red color development, but may stimulate ethylene production and ripening, whereas the ethylenereleasing compound CGA 15281 enhanced red color development without stimulating ripening (Murphey and Dilley, 1988). This was attributed to more rapid ethylene evolution from CGA 15281 than from ethephon at low fruit $\mathrm{pH}$ values. As expected, ethephon applied alone advanced maturity and stimu- 


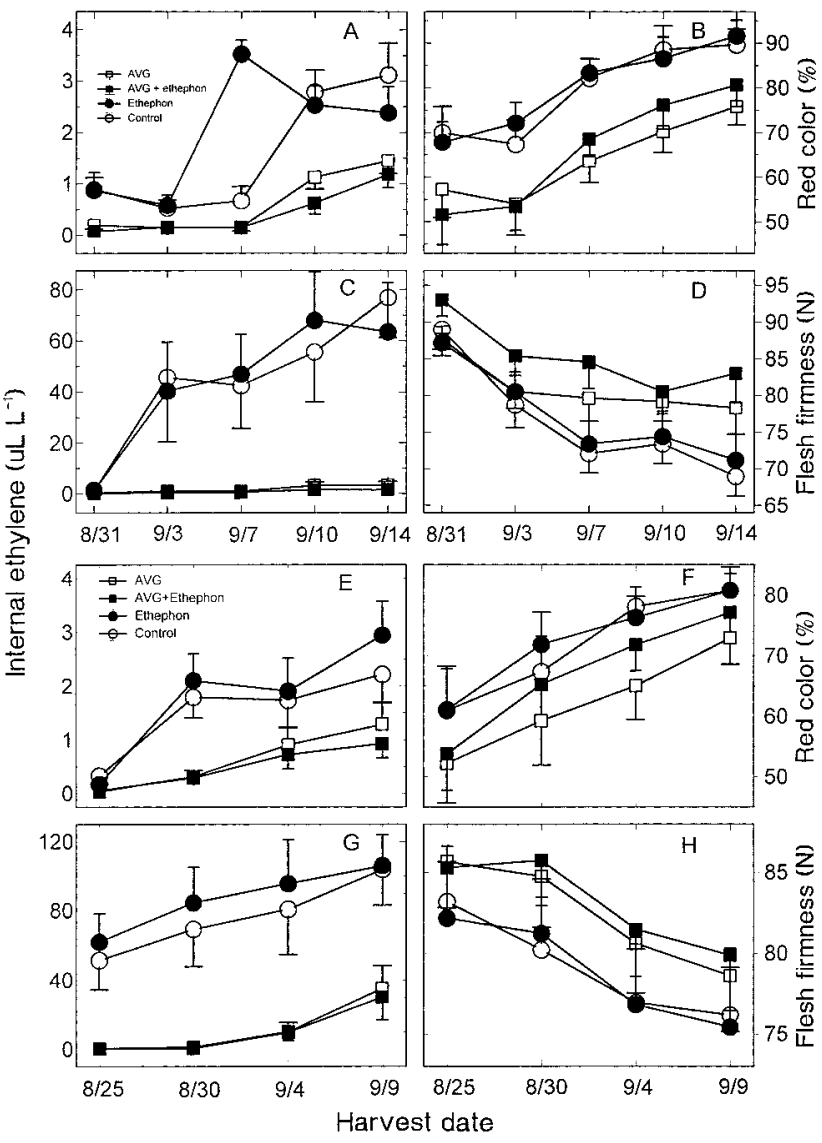

Fig. 1. Effects of AVG and/or ethephon on internal ethylene concentrations (A, $\mathbf{C}, \mathbf{E}, \mathbf{G})$, red color $(\mathbf{B}, \mathbf{F})$, and flesh firmness $(\mathbf{D}, \mathbf{H})$ of 'Gala' apple in 1998 $(\mathbf{A}, \mathbf{B}, \mathbf{C}, \mathbf{D})$ and in 1999 (E, F, G, H) at harvest $(\mathbf{A}, \mathbf{B}, \mathbf{E}, \mathbf{F})$ and after an additional $7 \mathrm{~d}$ at $20^{\circ} \mathrm{C}(\mathbf{C}, \mathbf{D}, \mathbf{G}, \mathbf{H})$. Rate of ethephon applied (a.i.) was 212 $\mathrm{g} \cdot \mathrm{ha}^{-1}$ in 1998 and $282 \mathrm{~g} \cdot \mathrm{ha}^{-1}$ in 1999 . AVG was used at $124 \mathrm{~g} \cdot \mathrm{ha}^{-1}$. The bars indicate SE for data points. Note that scale for internal ethylene differs among graphs.

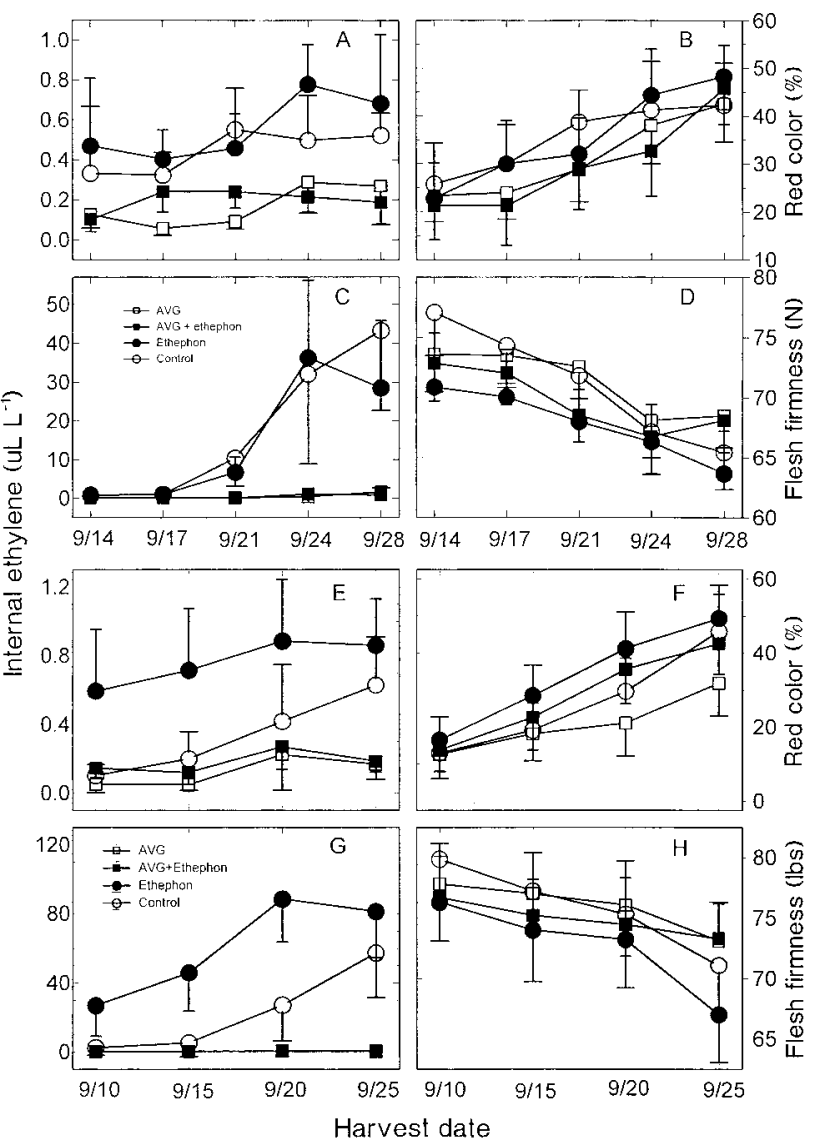

Fig. 2. Effects of AVG and/or ethephon on internal ethylene concentrations (A, C, E, G), red color $(\mathbf{B}, \mathbf{F})$, and flesh firmness $(\mathbf{D}, \mathbf{H})$ of 'Jonagold' apple in $1998(\mathbf{A}, \mathbf{B}, \mathbf{C}, \mathbf{D})$ and in $1999(\mathbf{E}, \mathbf{F}, \mathbf{G}, \mathbf{H})$ at harvest $(\mathbf{A}, \mathbf{B}, \mathbf{E}, \mathbf{F})$ and after an additional $7 \mathrm{~d}$ at $20^{\circ} \mathrm{C}(\mathbf{C}, \mathbf{D}, \mathbf{G}, \mathbf{H})$. Chemical treatments are as in legend to Fig. 1. The bars indicate SE for data points.
Table 1. The effect of AVG $\left(\right.$ ReTain $\left.^{\mathrm{TM}}\right)$ on internal ethylene, red color, and flesh firmness of 'Gala' and 'Jonagold' apples at harvest $(0 \mathrm{~d})$ and after $7 \mathrm{~d}$ at $20^{\circ} \mathrm{C}(7 \mathrm{~d})$.

\begin{tabular}{|c|c|c|c|c|c|}
\hline \multirow[b]{2}{*}{ Cultivar } & \multirow[b]{2}{*}{ Treatment $^{2}$} & \multicolumn{2}{|c|}{ Internal ethylene $\left(\mu \mathrm{L} \cdot \mathrm{L}^{-1}\right)$} & \multirow{2}{*}{$\begin{array}{l}\text { Red color (\%) } \\
0 \mathrm{~d} \\
\end{array}$} & \multirow{2}{*}{$\begin{array}{l}\text { Flesh firmness }(\mathrm{N}) \\
7 \mathrm{~d} \\
\end{array}$} \\
\hline & & $0 \mathrm{~d}$ & $7 \mathrm{~d}$ & & \\
\hline & & & 1998 & & \\
\hline \multirow[t]{4}{*}{ Gala } & AVG & $1.45 \mathrm{a}^{\mathrm{y}}$ & $3.35 \mathrm{a}$ & 75.8 a & $78.5 \mathrm{~b}$ \\
\hline & AVG+Eth & $1.18 \mathrm{a}$ & $1.50 \mathrm{a}$ & $80.6 \mathrm{a}$ & $83.0 \mathrm{c}$ \\
\hline & Ethephon & $2.38 \mathrm{~b}$ & $63.40 \mathrm{~b}$ & $91.6 \mathrm{~b}$ & $71.0 \mathrm{a}$ \\
\hline & Control & $3.12 \mathrm{c}$ & $76.90 \mathrm{~b}$ & $89.6 \mathrm{~b}$ & $69.0 \mathrm{a}$ \\
\hline \multirow[t]{5}{*}{ Jonagold } & AVG & $0.27 \mathrm{ab}$ & $1.52 \mathrm{a}$ & $42.5 \mathrm{a}$ & $68.5 \mathrm{~b}$ \\
\hline & AVG+Eth & $0.19 \mathrm{a}$ & $0.80 \mathrm{a}$ & $45.7 \mathrm{a}$ & $68.1 \mathrm{~b}$ \\
\hline & Ethephon & $0.68 \mathrm{c}$ & $28.50 \mathrm{~b}$ & $48.3 \mathrm{a}$ & $63.7 \mathrm{a}$ \\
\hline & Control & $0.52 \mathrm{bc}$ & $43.20 \mathrm{~b}$ & $42.3 \mathrm{a}$ & $65.4 \mathrm{ab}$ \\
\hline & & & 1999 & & \\
\hline \multirow[t]{4}{*}{ Gala } & AVG & $1.29 \mathrm{a}$ & $35.10 \mathrm{a}$ & $72.9 \mathrm{a}$ & $78.6 \mathrm{ab}$ \\
\hline & AVG+Eth & $0.93 \mathrm{a}$ & $30.20 \mathrm{a}$ & $77.2 \mathrm{~b}$ & $79.9 \mathrm{~b}$ \\
\hline & Ethephon & $2.94 \mathrm{c}$ & $106.00 \mathrm{~b}$ & $80.8 \mathrm{c}$ & $75.4 \mathrm{a}$ \\
\hline & Control & $2.21 \mathrm{~b}$ & $104.00 \mathrm{~b}$ & $80.8 \mathrm{c}$ & $76.2 \mathrm{ab}$ \\
\hline \multirow[t]{4}{*}{ Jonagold } & AVG & $0.17 \mathrm{a}$ & $0.32 \mathrm{a}$ & $31.8 \mathrm{a}$ & $73.1 \mathrm{~b}$ \\
\hline & $\mathrm{AVG}+\mathrm{Eth}$ & $0.18 \mathrm{a}$ & $0.65 \mathrm{a}$ & $41.2 \mathrm{~b}$ & $73.3 \mathrm{~b}$ \\
\hline & Ethephon & $0.86 \mathrm{~b}$ & $81.10 \mathrm{~b}$ & $49.3 \mathrm{~b}$ & $67.0 \mathrm{a}$ \\
\hline & Control & $0.63 \mathrm{ab}$ & $57.30 \mathrm{~b}$ & $49.2 \mathrm{~b}$ & $71.1 \mathrm{ab}$ \\
\hline
\end{tabular}

${ }^{2}$ The concentration of AVG was $124 \mathrm{~g} \cdot \mathrm{ha}^{-1}$ and the concentrations of ethephon were $212 \mathrm{~g} \cdot \mathrm{ha}^{-1}$ in 1998 , and $282 \mathrm{~g} \cdot \mathrm{ha}^{-1}$ in 1999.

${ }^{\mathrm{y}}$ Mean separation within columns, cultivars, and years by ANOVA at $P \leq 0.05$. lated ethylene production, ripening, and red color development each year. Similar results were obtained with 'Jonagold'. Results with AVG and AVG + ethephon treatments for both cultivars in 1998 and 1999 were more dramatic than in 1997 (Wang and Dilley, 1998) presumably because the trees experienced drought stress in 1997, whereas they were irrigated in 1998. The 1999 growing season was "typical" with ample rainfall and moderate temperatures.

The results from our 1999 experiment largely confirm those obtained in 1998, as well as in 1997 (Wang and Dilley, 1998), when an experiment was conducted in a similar manner in the same research plot. The experimental design for these experiments included at least three different rootstocks for each cultivar, plus different training systems and tree spacings for each replication. Despite this variability among trees, our results have been similar in most respects in three very different growing seasons. Based on our 1999 data, the ethephon usage rate was an important factor in improving red color development. This indicates that predictable responses can be obtained using a combination of these plant 
Table 2. Effects of 1999 AVG treatments on internal ethylene concentration, red color, and flesh firmness of 'Gala' and 'Jonagold' apples after 6 months of CA $\left(1.5 \% \mathrm{O}_{2}+3.0 \% \mathrm{CO}_{2}\right)$ storage plus $7 \mathrm{~d}$ poststorage at $20^{\circ} \mathrm{C}$. 'Gala' apples were harvested on 9 Sept. and 'Jonagold' on 25 Sept.

\begin{tabular}{lcccc}
\hline Cultivar & Treatment $^{\mathrm{z}}$ & Internal ethylene $\left(\mu \mathrm{L}^{\circ} \mathrm{L}^{-1}\right)$ & Red color $(\%)$ & Flesh firmness $(\mathrm{N})$ \\
\hline Gala & AVG & $0.16 \mathrm{a}^{\mathrm{y}}$ & $65.7 \mathrm{a}$ & $78.3 \mathrm{c}$ \\
& AVG+Ethephon & $0.14 \mathrm{a}$ & $71.3 \mathrm{~b}$ & $76.7 \mathrm{c}$ \\
& Ethephon & $0.40 \mathrm{~b}$ & $79.2 \mathrm{c}$ & $66.8 \mathrm{a}$ \\
Jonagold & Control & $0.41 \mathrm{~b}$ & $76.5 \mathrm{c}$ & $70.7 \mathrm{~b}$ \\
& AVG & $31.80 \mathrm{ab}$ & $25.1 \mathrm{a}$ & $66.7 \mathrm{~b}$ \\
& AVG+Ethephon & $20.20 \mathrm{a}$ & $39.3 \mathrm{~b}$ & $66.0 \mathrm{~b}$ \\
& Ethephon & $70.80 \mathrm{c}$ & $42.6 \mathrm{~b}$ & $63.3 \mathrm{a}$ \\
& Control & $51.90 \mathrm{bc}$ & $41.2 \mathrm{~b}$ & $65.0 \mathrm{ab}$
\end{tabular}

The concentration of AVG was $124 \mathrm{~g} \cdot \mathrm{ha}^{-1}$ and the concentration of ethephon was $282 \mathrm{~g} \cdot \mathrm{ha}^{-1}$ in 1999. ${ }^{\mathrm{M}}$ Mean separation within columns and cultivars by ANOVA at $P \leq 0.05$.

growth regulators to improve red color development while not overly stimulating fruit ripening.

The fruit maturity/ripening-related effects of the treatments were reflected in the storability of 'Gala' and 'Jonagold' fruit held in CA storage in 1999 (Table 2), where the action of ethylene on ripening can be attenuated. Fruit treated with $\mathrm{AVG}$, with or without ethephon, were still at preclimacteric ethylene levels after 6 months in CA storage and remained so after holding in air at $20^{\circ} \mathrm{C}$ for $7 \mathrm{~d}$, and flesh firmness and shelf-life were still excellent, especially for 'Gala'. Ethephon-only and control fruit had higher ethylene levels and softened during CA storage and shelf-life evaluation. These results confirmed our earlier observations (Wang and Dilley, 1998).

Collectively, our results show that AVG treatment at the commercially recommended time according to the label for $\operatorname{ReTain}^{\mathrm{TM}}(\approx 4$ to 6 weeks before normal harvest) and rate of application (124 $\left.\mathrm{g} \cdot \mathrm{ha}^{-1}\right)$, followed by an ethephon application at $282 \mathrm{~g} \cdot \mathrm{ha}^{-1} \approx 2$ weeks later, may improve fruit firmness and slow maturation without reducing red color development, whereas using AVG alone inhibits color development. Delaying the timing of the ethylene climacteric by AVG (Bangerth, 1978; Boller et al., 1979; Bufler, 1984, 1986; Halder-Doll and Bangerth, 1987) allows the would favor a once-over harvest of wellcolored, high-quality fruit, reducing harvest labor input; this would help offset chemical costs. Commercial trials employing a staggered AVG/ethephon application schedule have yielded similar results with several cultivars (A. Swindeman, Sela Heights, Wash., personal communication).

\section{Literature Cited}

Bangerth, F. 1978. The effect of a substituted amino acid on ethylene biosynthesis, respiration, ripening and preharvest drop of apple fruits. J. Amer. Soc. Hort. Sci. 103:401-404.

Boller, T., R.C. Herner, and H. Kende. 1979. Assay for and enzymatic formation of an ethylene precursor, 1-aminocyclopropane-1-carboxylic acid. Planta 145:293-303.

Bufler, G. 1984. Ethylene-enhanced 1-aminocyclopropane-1-carboxylic acid synthase activity in ripening apples. Plant Physiol. 75:192-195.

Bufler, G. 1986. Ethylene-promoted conversion of 1-aminocyclopropane-1-carboxylic acid to ethylene in peel of apples at various stages of development. Plant Physiol. 80:539-543.

Burg, S.P. and E.A. Burg. 1965. Gas exchange in fruits. Physiol. Plant. 18:870-884.

Halder-Doll, H. and F. Bangerth. 1987. Inhibition of autocatalytic $\mathrm{C}_{2} \mathrm{H}_{4}$ biosynthesis by AVG applications and consequences on the physiological behavior and quality of apple fruits in cool storage. Scientia Hort. 33:87-96.

Kneissl, M. and J. Deikman. 1999. The tomato E8 gene influences ethylene biosynthesis in fruit but not in flowers. Plant Physiol. 112:537-547.

Lashbrook, C.C., D.M. Tieman, and H.J. Klee. 1999. Differential regulation of the tomato ETR gene family throughout plant development. Plant J. 15:243-252.

Murphey, A.S. and D.R. Dilley. 1988. Anthocyanin biosynthesis and maturity of 'McIntosh' apples as influenced by ethylene-releasing compounds. J. Amer. Soc. Hort. Sci. 113:718-723.

Shafer, W.E., G. Clarke, J. Hansen, D. Woolard, B.N. Devisetty, and R. Fritts. 1995. Practical applications of aminoethoxyvinylglycine. Proc. Plant Growth Regulat. Soc. Amer. 1995:11-15.

Wang, Z. and D.R. Dilley. 1998. Enhancing anthocyanin production and maturity uniformity of apples without over-ripening. Proc. Mich. State Hort. Soc. 128:67-77. 